\title{
PROCESSES AFFECTING RECENT AND FUTURE MORPHOLOGICAL EVOLUTION OF THE XYLOKASTRO BEACH ZONE (GULF OF CORINTH, GREECE)
}

\author{
VALAOURIS A. ${ }^{1}$ \\ POULOS S., \\ PETRAKIS $S^{1}$ \\ ALEXANDRAKIS G. ${ }^{2}$ \\ VASSILAKIS E. ${ }^{1}$ \\ GHIONIS G. ${ }^{1}$
}

\author{
${ }^{1}$ Department of Geography \& Climatology \\ Faculty of Geology \& Geoenvironment \\ University of Athens, Panepistimioupolis, Zografou, 15784, Greece \\ ${ }^{2}$ Institute of Applied and Computational Mathematics \\ Foundation for Research and Technology, Hellas \\ Nikolaou Plastira 100, Vassilika Vouton,70013 Heraklion, Crete Greece
}

Received: 02/10/2013

Accepted: $17 / 07 / 2014$

*to whom all correspondence should be addressed:

Available online: 13/10/2014 e-mail:poulos@geol.uoa.gr

\section{ABSTRACT}

The aim of the present study is to investigate the morphodynamic regime of the coastal area of Xylokastro (north coast of Peloponnese), in order to identify and evaluate the processes controlling its formation and evolution. Within this concept, a number of factors have been considered and evaluated; near-shore morphometry and granulometry along shore-normal profiles, the direction and potential volumes of long- and cross-shore sediment transport the decadal and future trends of coastline displacement, the available information for terrestrial sediment influx and the geological processes operating in the broader coastal region of Xylokastro (i.e. subaqueous slides) as well as human interference. On the basis of these results, the formation and evolution of this coastal stretch seems to be governed primarily by the neotectonic activity and relative change of sea level rise, and secondarily by the wave-induced near-shore sediment transport; the role of the latter could be enhanced substantially by human intervention (i.e. construction of marina, seafront walls). Moreover, the expected eustatic increase in sea level by the year 2100, could cause a coastline retreat up to $9 \mathrm{~m}$ $(\mathrm{SLR}=0.38 \mathrm{~m})$ or $>19 \mathrm{~m}(\mathrm{SLR} \geq 1 \mathrm{~m})$.

Keywords: wave regime, coastline changes, erosion, climate change

\section{Introduction}

Beach zone formation and evolution being among the most sensitive coastal environments, is controlled by the interaction of physical factors and anthropogenic intervention (direct or indirect). Physical factors include morphology of the inner continental shelf (width, slope), tectonic activity, relative sea level change, terrestrial (mostly fluvial) sediment influx, near-shore hydrodynamics and sediment dynamics. Human intervention may relate to waterfront engineering (e.g. marinas), dune field deterioration, of the river basin regulation, as well as dredging/damping and abstraction of beach zone material.

Beach erosion, which is already a major global problem (e.g. Eurosion, 2004; Cai et al., 2009), can be differentiated into: (i) long-term erosion, i.e. irreversible retreat of the shoreline position due to mean sea level rise and/or negative coastal sedimentary budgets (e.g. Dan et al., 2009); and (ii) short-term erosion, caused by storms/storm surges, which may (Castelle et al., 2008) or may not (List et al., 2006) result in permanent shoreline retreats, but could nevertheless be devastating (e.g. Fritz et al., 2010). 
Moreover, within the context of climate change, the projected mean sea level rise (e.g. Rahmstorf, 2007) will likely exacerbate the already considerable beach erosion (e.g. Nicholls et al., 2007) and severely affect coastal populations, activities, infrastructure and assets (e.g. McGranahan et al., 2007).

The beach zone under investigation is under erosion (locally extensive), although it is exposed to low wave energy, being located on the south coast of the semi-enclosed Gulf of Corinth. It should be noted that there are not many studies worldwide on semi-enclosed, low wave energy environments (e.g. Ryu, 2003), since in most cases, studies concern open sea coasts and/or highly energetic coastal environments. Studies that refer exclusively to the Mediterranean Sea are those of Frihy \& Lotfy, (1997); Perlin and Kit, (1999); Mendoza and Jimenez, (2006); Zviely et al., (2007); Sánchez-Arcilla et al., (2008); Alexandrakis and Poulos (2014). Additionally, the coastal zone under investigation is influenced by intensive seismotectonic activity, as it belongs to the south flank of the tectonic graben of the Gulf of Corinth (i.e. North Peloponnese) that is subdued to a tectonic uplift of about $1 \mathrm{~mm}$ year ${ }^{-1}$ during Quaternary (Doutsos et al., 1988).

The aim of this study is to investigate and link both the physical processes and the impact of the human interference that control the formation and evolution of the coastal front of Xylokastro town, with emphasis on the present and future shoreline position, by combining several classic and state of the art techniques, such as sediment sampling and analysis, beach profile measurements, mathematical calculations of nearshore sediment transport, remote sensing and DGPS surveying.

\section{The study area}

Geologically, the broader Xylokastro region is partially controlled by several north dipping active normal faults, almost parallel to the present coastline, which contribute to the ongoing widening of the Corinth Gulf rift; this has been verified by various GPS campaigns (e.g. Briole et al., 2000; Hollenstein et al., 2008). Furthermore, Vassilakis et al. (2011), after recomputing the raw data from several GPS campaigns have suggested an almost E-W trending - normal faulting extension of the Gulf in the order of 14 $\mathrm{mm}$ year $^{-1}$, along the NNW-SSE trend. The higher uplift rates were identified in the area between Aegio and Xylokastro being 1.0-1.28 $\mathrm{mm} \mathrm{yr}^{-1}$ (Armijo et al., 1996; McNeil \& Collier, 2004), while the lowest uplift rates were observed farther to the east and are estimated to be about $0.3 \mathrm{~mm} \mathrm{yr}^{-1}$ near the city of Corinth and the Perachora peninsula (Collier et al., 1992).

The lower route of the R. Sithas that debouches at Xylokastro town, as most of the other rivers outflowing in the south coast of the Gulf of Corinth, has been tectonically affected due to southwards tilting of the block to which it belongs (Vassilakis et al., 2007). Moreover, the associated seismic activity causes sediment instability in the shelf and slope areas of the Gulf (e.g. Heezen et al., 1966; Perissoratis et al., 1984; Ferentinos et al., 1988; Doutsos and Piper, 1990; Lykousis, 1991; Papatheodorou \& Ferentinos, 1997; Hasiotis et al., 2002; McNeill et al., 2005).

The study area is located in the central part of North Peloponnese and includes the sea front of Xylokastro town (fig. 1), extending $5 \mathrm{~km}$ in length. The beach zone is the seaward limit of a low-lying alluvial plain, whose central part incorporates the deltaic alluvial cone of the Sithas River. The latter provides approximately $0.1710^{6}$ tonnes of sediment, annually (Gourdoubas et al., 2010). The overall subaqueous morphology reveals a rather narrow and steep shelf, even in front of the mouth area of Sithas river. Besides, a series of human interventions (usually associated to touristic development and recreational activities) have also affected the beach zone sediment budget either directly (i.e. breakwaters, seafront wall, ports) and/or indirectly (i.e. river flow regulation).

From the oceanographic point of view, the study is characterized as micro-tidal, as the contribution of the astronomical tide is very small $(<20 \mathrm{~cm}$, after Tsimplis (1994)). On the contrary, due to the closed morphology of the gulf, westerly winds can produce a rise of sea surface elevation in excess of $1 \mathrm{~m}$, according to the tidal gauge at Poseidonia (HNHS, 2005). Wave energy is expected to be low due to the limited fetch distances $(<42 \mathrm{~km})$, whilst swell is also related to westerly directions and is expected to have very small contribution to the overall nearshore hydrodynamics. 


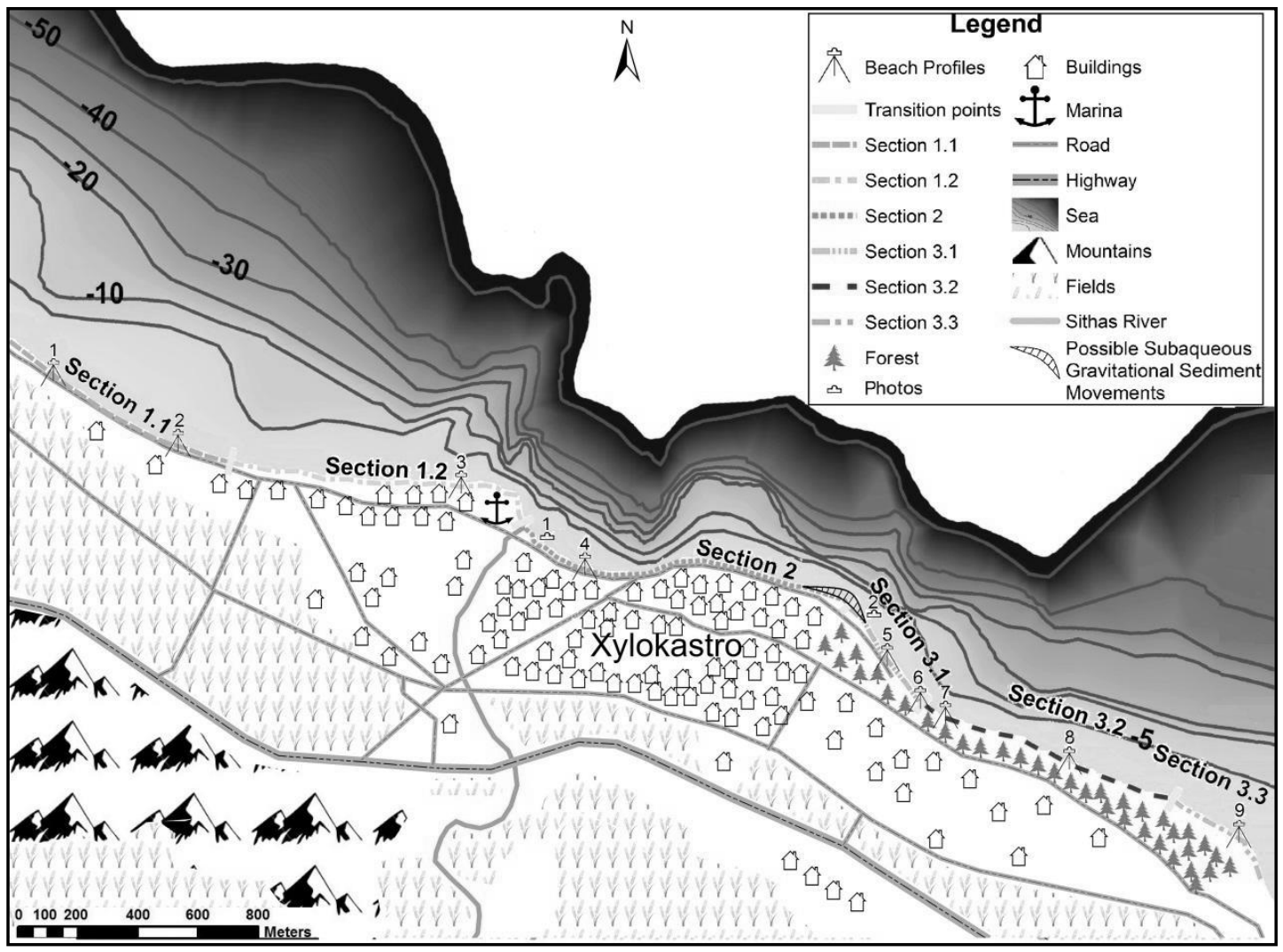

Figure. 1: The beach zone of the Xylokastro coast (Gulf of Corinth).

For the needs of the present investigation, the study area is divided into three main sections (see fig. 1): The western section (1), where the beach zone is rather narrow and sparsely populated; the central section (2), which is strongly affected by human intervention (i.e. regulation of Sithas River mouth, construction of a tourist marina and a seawall to protect the buildings reaching the coastline); and the eastern section (3) that "hosts" Pefkias pine-forest, vegetated on a low relief dune field.

\section{Materials and methods}

Morphodynamic measurements were conducted on nine representative shore-normal profiles (for locations see fig. 1), with the use of a laser distance meter (Leica DISTO A8) and a portable simple beam echo-sounder (Hondex PS-7), extending from the backshore to the water depth of about $5 \mathrm{~m}$. Along the nine profiles, 29 samples (both subaqueous and subaerial) were collected and analysed granulometrically according to Folk's (1974) procedure. The present position of the shoreline was traced by using differential GPS and real time kinematics procedures (HiperPro, Topcon) of less than $1 \mathrm{~cm}$ accuracy.

The calculation of potential longshore sediment transport $\left(Q_{L}\right)$ was conducted utilizing the equations provided by the CERC (1984) for all incoming wave directions and breaking wave heights $>0.2 \mathrm{~m}$. The estimation of the required wave breaking conditions (i.e., wave height $\left(H_{b}\right)$, depth of breaking $\left(h_{b}\right)$ and breaking angle $\left(a_{b}\right)$ ) were calculated with the use of CEDAS 2.01f, while the initial offshore conditions (significant wave height and period) have been abstracted from Ghionis \& Ferentinos (2002), who have hindcasted the offshore wave conditions using wind data from the National Meteorological Service of Greece and the semi-empirical prognostic equations of CERC (1984).

An estimate of the annual cross-shore sediment transport rates (although it is considered as indicative) has been calculated using Bailard \& Inman's, (1981) equation: 
$\mathrm{Q}_{\mathrm{c}}=\mathrm{pC}_{\mathrm{D}} \mathrm{u}_{\mathrm{m}}^{3}\left\{\frac{\varepsilon_{\mathrm{B}}}{\tan \phi}\left(\Psi_{1}+\frac{2}{3} \delta_{\mathrm{u}}-\frac{\tan \beta}{\tan \phi} \mathrm{u}_{5}^{*}\right)+\frac{\mathrm{u}_{\mathrm{m}}}{\mathrm{w}_{\mathrm{s}}} \varepsilon_{\mathrm{s}}\left[\Psi_{2}+\delta_{\mathrm{u}} \mathrm{u}_{3}^{*}-\frac{\mathrm{u}_{\mathrm{m}}}{\mathrm{w}_{\mathrm{s}}} \varepsilon_{5} \mathrm{u}_{5}^{*} \tan \beta\right]\right\}$

where, $\varepsilon_{B}=0.2 ; \varepsilon_{S}=0.025 ; C_{D}$ : dragging coefficient; $w_{s}$ : sediment fall velocity; $\phi$ : angle of repose; $\beta$ : beach slope; $u_{b}$ : near bed water velocity; $\rho$ : water density; and, $\rho_{s}$ : density of sediment.

The velocity components $u_{m}, u_{3}{ }^{*}$ and $u_{5}{ }^{*}$ (in $\mathrm{cm} \mathrm{s}^{-1}$ ), the normalized mean onshore current $\delta_{u}$ as well as $\psi_{1}$ and $\psi_{2}$ skewness parameters were estimated from the significant wave height $\mathrm{H}_{\mathrm{s}}(\mathrm{in} \mathrm{cm})$, using the regression equations for data from the NSTS Torrey Pines experiment (Bailard, 1982): $\delta_{\mathrm{u}}=0.458+0.00157$ $\mathrm{H}_{\mathrm{s}} ; \mathrm{u}_{\mathrm{m}}=31.9+0.403 \mathrm{H}_{\mathrm{s}} ; \mathrm{u}_{3}{ }_{3}=0.548+0.000733 ; \mathrm{u}_{5}^{*}=1.5-0.00346 \mathrm{H}_{\mathrm{s}} ; \Psi_{1}=0.303-0.00144 \mathrm{H}_{\mathrm{s}} ;$ and $\Psi_{2}=0.603-$ $0.0051 \mathrm{H}_{\mathrm{s}}$.

For the direction of the cross-shore sediment transport the Hattori and Kawamata (1980) equation was used:

$\frac{\mathrm{g} \mathrm{H}_{\mathrm{o}} \tan \beta \mathrm{T}}{\mathrm{L}_{\mathrm{o}} \mathrm{W}_{\mathrm{s}}}\left\{\begin{array}{l}>0.5 \text { (offshore) } \\ <0.5 \text { (onshore) }\end{array}\right.$

The settling velocity for different ranges of grain size (D) is given by Van Rijn's (1993) equations:

$$
\begin{array}{ll}
W_{s}=\frac{1}{18} \frac{\sigma-\rho}{\rho} d \frac{D^{2}}{v} & 1<D<100 \mu m \\
W_{s}=\frac{10 v}{d}\left[\left(1+\frac{\sigma-\rho}{\rho} \frac{0.01 \mathrm{gD}^{3}}{v^{2}}\right)^{0.5}-1\right] & 100<D<1000 \mu \mathrm{m} \text { and } \\
W_{s}=1.1\left(\frac{\sigma-\rho}{\rho} g D\right)^{0.5} & D>1000 \mu m
\end{array}
$$

where, $\sigma$ : sediment density $\left(\sim 2650 \mathrm{~kg} \mathrm{~m}^{-3}\right)$, $\rho$ : density of seawater $\left(\sim 1025 \mathrm{~kg} \mathrm{~m}^{-3}\right), \mathrm{g}=9.81 \mathrm{~m} \mathrm{~s}^{-2}$, D: grain diameter $(\mu \mathrm{m})$, v: sea water kinematic viscosity $\left(\sim 110^{-6} \mathrm{~m}^{2} \mathrm{~s}^{-1}\right)$.

The latest long-term coastline changes were identified through the comparison of topographic maps (1:5,000, published during the 1970's by the Hellenic Geographic Military Service), with ortho-photo maps (interpreted aerial ortho-photographs of 1996), high spatial resolution satellite images (IKONOS-2 acquired during 2000) and the traced coastline by the RTK-DGPS survey on March 2011. The comparison of the coastlines took place after digitizing them with the use of a Geographic Information System platform (ArcGIS), projecting them in the same projection system (HGRS'87).

Finally, future coastline evolution (retreat) due to the anticipated sea level rise (Rc) was calculated by Dean's (1991) semi-empirical equation, which combines sea level change and wave impact (storm conditions):

$R_{c}=\left(S+0.068 H_{b}\right) \frac{W_{s}}{d_{b}+B}$

where, S: relative mean sea level rise; $W_{s}$ (surf zone length): the horizontal distance from the wave breaking point to the coastline; $B$ :the highest terrestrial berm height; $H_{b}$ : wave breaking height; and, $d_{b}$ : breaking depth (all in meters).

\section{Results and Discussion}

\subsection{Beach zone morphology}

The western part of the study area is characterised by a rather narrow (less than $10 \mathrm{~m}$ wide) subaerial beach zone, with the exception of the beach on the west side of the small harbor due to sediment accumulation resulting from the eastward long-shore sediment transport. 


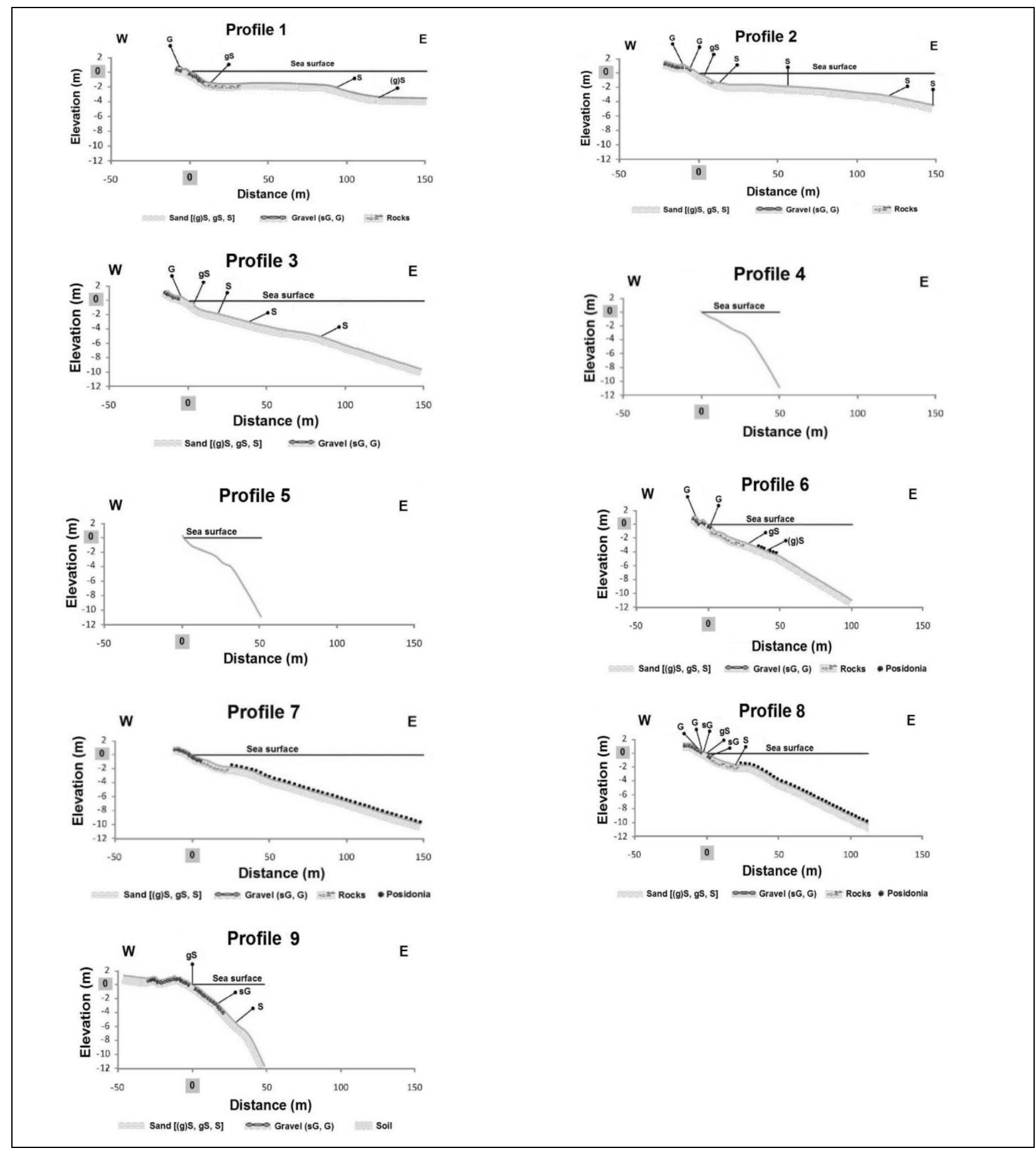

Figure 2: Profiles normal to shoreline, seabed texture and sediment samples of the Xylokastro beach zone (for locations see Fig. 1).

In addition, a part of the beach section 1.2 has been eroded totally; this seems to be associated with the near-shore bathymetry; the reduced distance between the $5 \mathrm{~m}$ isobaths and the coastline that increases the erosive ability of the incoming waves. The subaerial part consists mostly of sand, with relatively coarser material on the beach face. The subaqueous part deepens smoothly towards the $5 \mathrm{~m}$ isobath (profiles 1-3, figure 2), with increasing slopes eastwards, while it is composed of sandy material. The central part (section 2), extending to the east of the River Sithas mouth, is considerably deprived of the subaerial part of the beach zone, being the seafront of Xylokastro town protected by a seawall. The subaqueous part is rather steep (profile 4, figure 2), consisting of mixed material (sand and gravels). The 
eastern part of the beach zone under investigation is the seaward natural extension of the low relief dune field covered with pine trees. It consists of mixed material to a water depth of 2-3 m, whilst its deeper part is covered with Poseidonia, further indicating the stability of the seabed (profiles 7 and 8 , figure 2). Profile 9, at the eastern end of the study area, is steep and subaqueous and characterized by the lack of fine-grained material.

\subsection{Near-shore hydrodynamics and sediment movement}

\subsubsection{Wave regime}

The study area, owing to its orientation, is exposed mainly to northerly wind-generated waves (i.e. $\mathrm{N}$, $\mathrm{NW}, \mathrm{NE}$ ) and to a lesser extent to eastern winds. The wind with the greatest frequency of occurrence is the NW (46.7\%), followed by the N (3.7\%), NE (1.8\%) and E (0.4\%).

Table 1. The estimated offshore significant wave height $\left(H_{s}\right)$ and period $\left(T_{p}\right)$, along with the corresponding wind speeds $\left(U_{a}\right)$ and their frequency of occurrence $(f)$, in the case of the average (weighted to annual frequency of occurrence), most frequent and maximum wind-induced wave conditions.

\begin{tabular}{|c|c|c|c|c|}
\hline Wind direction & $f(\%)$ & $U_{a}\left(m^{-1}\right)$ & $T_{p}(s)$ & $\mathrm{H}_{\mathrm{s}}(\mathrm{m})$ \\
\hline \multicolumn{5}{|c|}{ Average $^{1}$ conditions } \\
\hline NW & 46.72 & 3.34 & 2.77 & 0,28 \\
\hline $\mathbf{N}$ & 3,70 & 4.50 & 3.19 & 0.40 \\
\hline NE & 1.80 & 4.97 & 3.07 & 0.39 \\
\hline $\mathbf{E}$ & 0.40 & 2.11 & 1.75 & 0.11 \\
\hline \multicolumn{5}{|c|}{ Most frequent conditions } \\
\hline NW $(2 \mathrm{~B})^{2}$ & 18.90 & 3.16 & 2.62 & 0.25 \\
\hline $\mathbf{N}(3 \mathrm{~B})$ & $2.16(3 B)(3 b)$ & 5.93 & 2.84 & 0.38 \\
\hline NE (3 B) & 0.90 & 5.93 & 3.04 & 0.42 \\
\hline$E(1 \mathrm{~B})$ & 0.20 & 1.35 & 1.12 & 0.04 \\
\hline \multicolumn{5}{|c|}{ Maximum conditions } \\
\hline NW (7 B) & 0.01 & 25.74 & 5.32 & 2.04 \\
\hline$N(5 B)$ & 0.03 & 14.76 & 3.86 & 0.95 \\
\hline NE (6 B) & 0.02 & 20.11 & 4.57 & 1.44 \\
\hline$E(5 B)$ & 0.01 & 14.76 & 3.38 & 0.61 \\
\hline
\end{tabular}

Key (1): weighted average with respect to the annual frequency of occurrence; (2): Beaufort scale

Note: Fetch distances: $\mathrm{NW}=41.36 \mathrm{~km} ; \mathrm{N}=29.65 \mathrm{~km} ; \mathrm{NE}=23.92 ; \mathrm{E}=32.52$

As shown in table 1 , the most frequently observed waves in the studied area develop heights of $\sim 25 \mathrm{~cm}$ and are induced by NW winds of 2 Beaufort wind force. The maximum wave heights are induced by NW winds and they are approximately $2 \mathrm{~m}$ in height. However, they are observed rarely.

\subsubsection{Near-shore sediment transport}

Near-shore sediment transport involves the estimation of the transport rates along and across the shoreline. In this study, long-shore and cross-shore sediment transport have been calculated for the potential transport of sediment; thus, these estimates are used as indicative, whilst the emphasis has been placed on their inter-relationship, in terms of quantity and direction, and on their association to long term changes of shoreline position.

With respect to the Potential Long-shore Sediment Transport (PLST), as it can be seen in Table 2, the NW wind has, by far, the most significant contribution in the PLST, moving southeastwards an average sediment volume of approximately $5.210^{4} \mathrm{~m}^{3} \mathrm{yr}^{-1}$. The second in order rate of PLST is induced by the north incoming waves, i.e. $1.910^{4} \mathrm{~m}^{3} \mathrm{yr}^{-1}$. The dominance of the long-shore sediment transport, induced 
by the NW incoming waves, is attributed to their higher frequency of occurrence (46.7\%), in relation to the other three wind/wave directions. Overall, in the western part (zones 1 and 2) and in the central region of the eastern part (section 3.2) the PLST is directed eastwards, with annual mean values in the order of 8.2-13.4 $10^{4} \mathrm{~m}^{3}$, whilst in sections 3.1 and 3.3 the PLST is directed to the west, but with much smaller quantities $\left(<2.510^{4} \mathrm{~m}^{3}\right)$.

Table 2. Potential rates of longshore sediment transport (in $10^{3} \mathrm{~m}^{3} \mathrm{yr}^{-1}$ ), induced by the prevailing windinduced wave directions, for each section of the Xylokastro beach zone (for the locations of the sections see Fig. 1).

\begin{tabular}{ccccccc}
\hline & Zone 1 & Zone 2 & \multicolumn{5}{c}{ Zone 3 } \\
\cline { 1 - 3 } & (Section 1.1 \& 1.2) & & Section 3.1 & Section 3.2 & Section 3.3 & Average \\
\hline NW & 110.24 & 96.32 & 2.12 & 50.64 & 0.4 & 51.94 \\
\hline $\mathbf{N}$ & 28.64 & 30.72 & 14.31 & 35.25 & -12.87 & 19.21 \\
\hline $\mathbf{N E}$ & -5.19 & -3.88 & -17.48 & -3.68 & -12.60 & -8.57 \\
\hline $\mathbf{E}$ & -0.04 & -0.05 & -0.05 & -0.06 & -0.03 & -0.05 \\
\hline Sum & $\mathbf{1 3 3 . 6 5}$ & $\mathbf{1 2 3 . 1 1}$ & $\mathbf{- 1 . 1 0}$ & $\mathbf{8 2 . 1 5}$ & $\mathbf{- 2 5 . 1 0}$ & \\
\hline
\end{tabular}

The Potential Cross-shore Sediment Transport (PCST) has been calculated for the 9 shore normal profiles, where sediment texture and slopes are known. On the basis of these calculations (Table 3), PCST has an onshore direction in the western section and in the eastern part of the eastern section, with values between 4.7 and $6.510^{4} \mathrm{~m}^{3}$. In the central part, the PCST is directed seawards, with values ranging from $3.210^{4} \mathrm{~m}^{3}$ to $-3.910^{4} \mathrm{~m}^{3}$ (profiles 4 and 5) to approximately $610^{4} \mathrm{~m}^{3}$ (profiles 6 and 7).

Table 3. Potential cross-shore sediment transport (in $10^{3} \mathrm{~m}^{3} \mathrm{yr}^{-1}$ ), estimated for each of the nine shorenormal profiles (for location see fig. 1) and for the four prevailing wind-induced wave directions.

\begin{tabular}{lccccccccc}
\hline \multicolumn{1}{c}{} & \multicolumn{1}{c}{ Section } \\
\hline $\mathbf{s}$ & $\mathbf{1 . 1}$ & $\mathbf{1 . 2}$ & $\mathbf{2}$ (west) & $\mathbf{3 . 1}$ (west) & $\mathbf{3 . 1}$ (east) & $\mathbf{3 . 2}$ & $\mathbf{3 . 3}$ \\
\hline Profile: & $\mathbf{1}$ & $\mathbf{2}$ & $\mathbf{3}$ & $\mathbf{4}$ & $\mathbf{5}$ & $\mathbf{6}$ & $\mathbf{7}$ & $\mathbf{8}$ & $\mathbf{9}$ \\
\hline $\mathbf{N}$ & -2.27 & -2.84 & -1.97 & 1.62 & 1.14 & 2.19 & 2.22 & 2.25 & -2.86 \\
\hline $\mathbf{N W}$ & -28.08 & -34.35 & -24.61 & 21.13 & 16.34 & 27.13 & 27.47 & -27.75 & -34.58 \\
\hline E & -24.02 & -28.39 & -21.15 & 16.29 & 15.26 & -23.07 & -23.40 & -23.51 & -28.76 \\
\hline Total & -54.37 & -65.58 & -47.73 & 39.03 & 32.73 & 6.25 & 6.29 & -49.01 & -66.20 \\
\hline
\end{tabular}

Note: Negative values correspond to onshore sediment movement.

The comparison of long-shore and cross-shore potential annual rates of sediment transport revealed that the PLST plays the dominant role in beach zone evolution, being 2-3 times greater than the corresponding PCST. On the other hand, it is also evident that the onshore PCST is associated with the presence of wider (more developed) parts of the beach zone under investigation. Additionally, the absence of subaerial beach zone in the central part of the Xylokastro beach zone may also be attributed (even partially) to the prevailing offshore PCST, without ignoring, however, the role of the various anthropogenic interferences.

\subsection{Shoreline position changes (recent and future)}

The maximum rates of the horizontal shoreline displacement along with their average values for the various sections of the coastal zone under investigation are presented in table 4 . It has to be mentioned that differences in coastline position in the order of a few meters may not be depicted, being within the accuracy range of the applied method. 
Table 4. Horizontal distance (in $\mathrm{m}$ ) of shoreline displacement along the Xylokastro coastal front for different time periods.

\begin{tabular}{cccccccc}
\hline & \multicolumn{7}{c}{ Section } \\
\cline { 2 - 8 } & Displacement & $\mathbf{1 . 1}$ & $\mathbf{1 . 2}$ & $\mathbf{2}$ & $\mathbf{3 . 1}$ & $\mathbf{3 . 2}$ & $\mathbf{3 . 3}$ \\
\hline \multirow{3}{*}{ 1970-1996 } & Max. Retreat & -18 & -6 & -37 & -40 & - & -1 \\
\cline { 2 - 8 } & Max. Advance & +14 & +34 & +16 & +16 & +17 & +17 \\
\cline { 2 - 8 } & Average change & -4 & +10 & -20 & -23 & +10 & +5 \\
\hline \multirow{2}{*}{$1996-2011$} & Max. Retreat & -13 & -17 & - & -19 & -18 & -18 \\
\cline { 2 - 8 } & Max Advance & +5 & +5 & - & - & - & - \\
\cline { 2 - 8 } & Average change & -3 & -14 & - & -12 & -10 & -5 \\
\cline { 2 - 7 } & Max. Retreat & -21 & -14 & -37 & -53 & -11 & -9 \\
\cline { 2 - 7 } & Max. Advance & +7 & +38 & +16 & +8 & +10 & +14 \\
\cline { 2 - 7 } & Average change & -8 & -6 & -20 & -35 & \pm 1 & \pm 1 \\
\hline
\end{tabular}

For the period 1970-1996, the average change in coastline position varies from $-23 \mathrm{~m}$ (retreat) to $+10 \mathrm{~m}$ (progradation), revealing a mixed state of evolution. On the contrary, for the 1996-2011 time period the entire coastline is subjected to retreat, with average values up to $14 \mathrm{~m}$. Furthermore, considering the entire time period (1970-2011), the western part retreated by no more than $8 \mathrm{~m}$, whilst the central part retreated from 20 to $35 \mathrm{~m}$ and the eastern part seems to have remained rather stable. Photographs in figures 3 and 4 depict positions of extended coastline retreat.

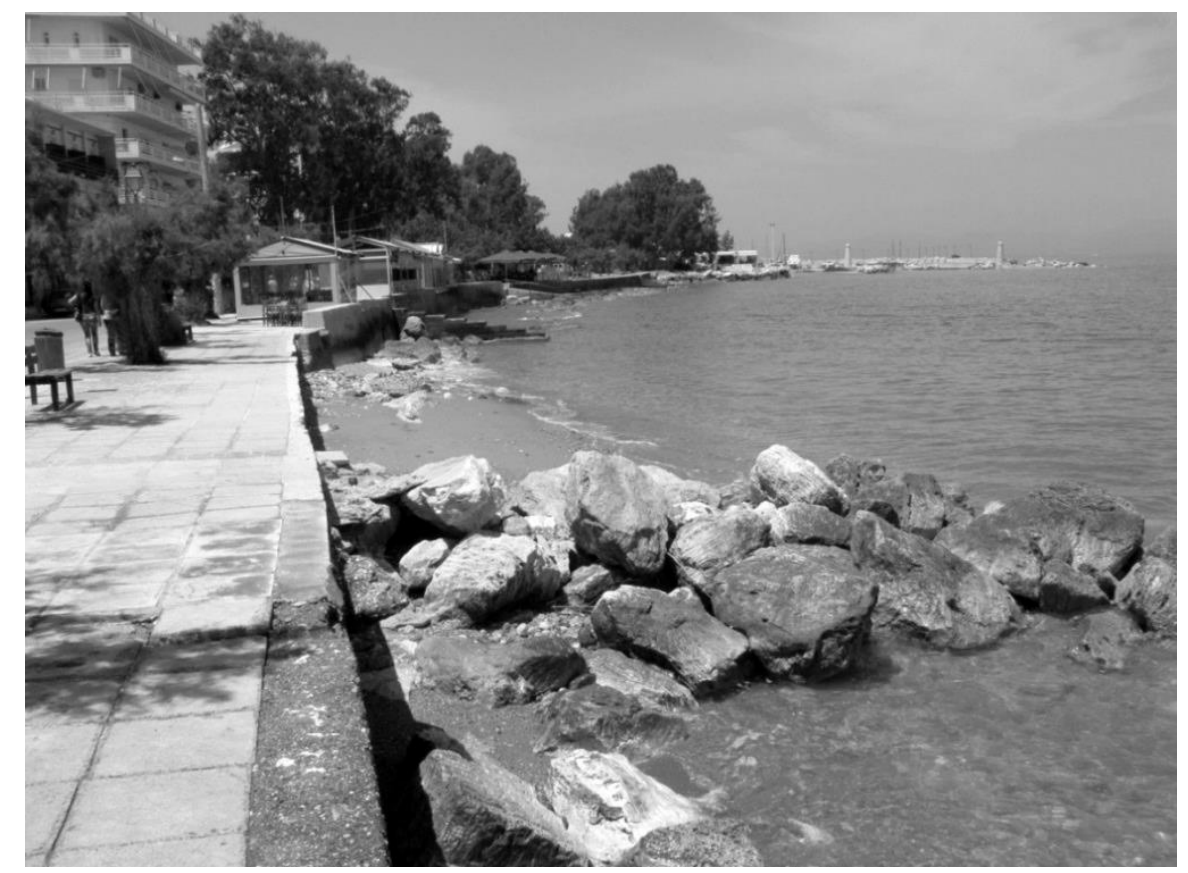

Figure 3: Photograph from the central part of the study area, where the coastline has retreated up to 37 m (from 1970 to 1996).

The aforementioned observations are in good agreement with both the magnitude and the direction of PLST and PCST; thus, in the western part, a relatively strong PLST undergoes, compensated partially by the onshore PCST. The central part is dominated either by a strong PLST and/or offshore PCST. Finally, the rather stable eastern part is favored by the onshore PCST and the relatively lower values of the PLST. In addition, the most extended coastline retreat (some $53 \mathrm{~m}$ ) observed in section 3.1 is associated also 
with a coastal subaqueous gravitational sediment movement that took place in the $1970 \mathrm{~s}$ ( $\mathrm{Dr}$ G. Ghionis pers. com.). Such gravitational mass movements are usual in the tectonically active Gulf of Corinth (as presented in section 2).

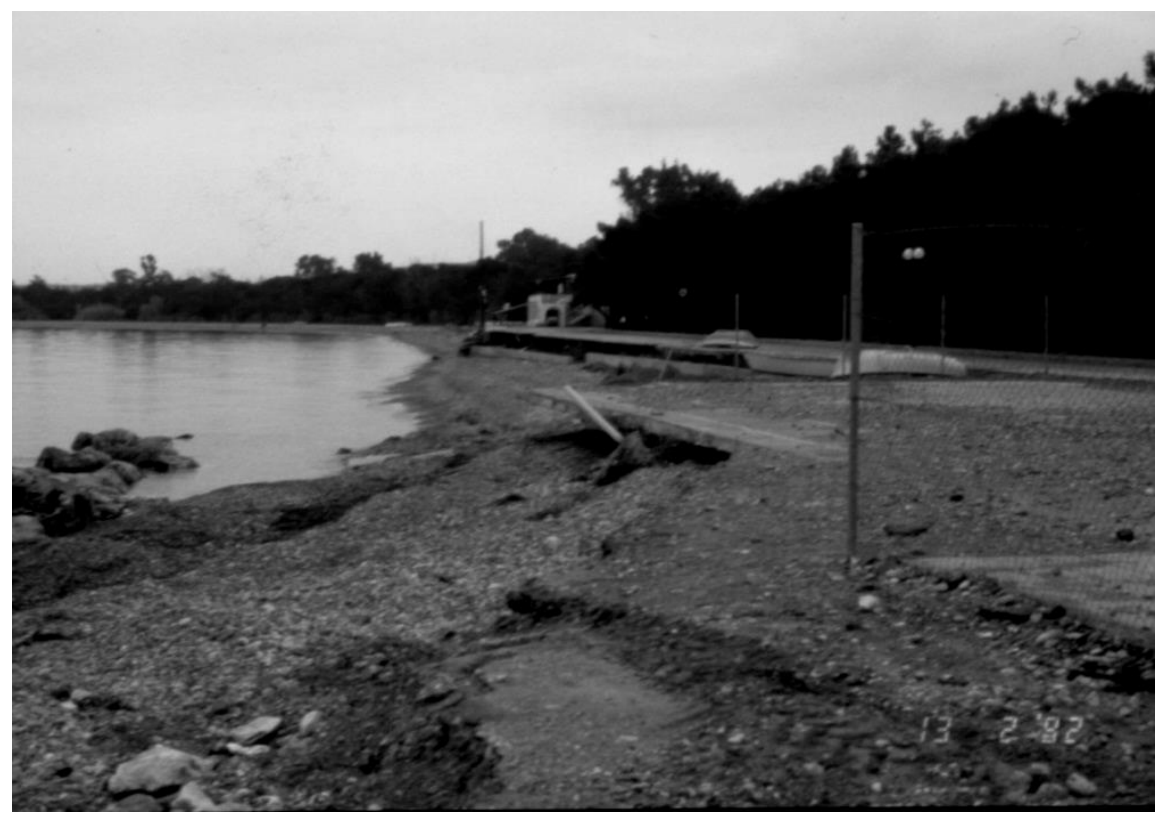

(a)

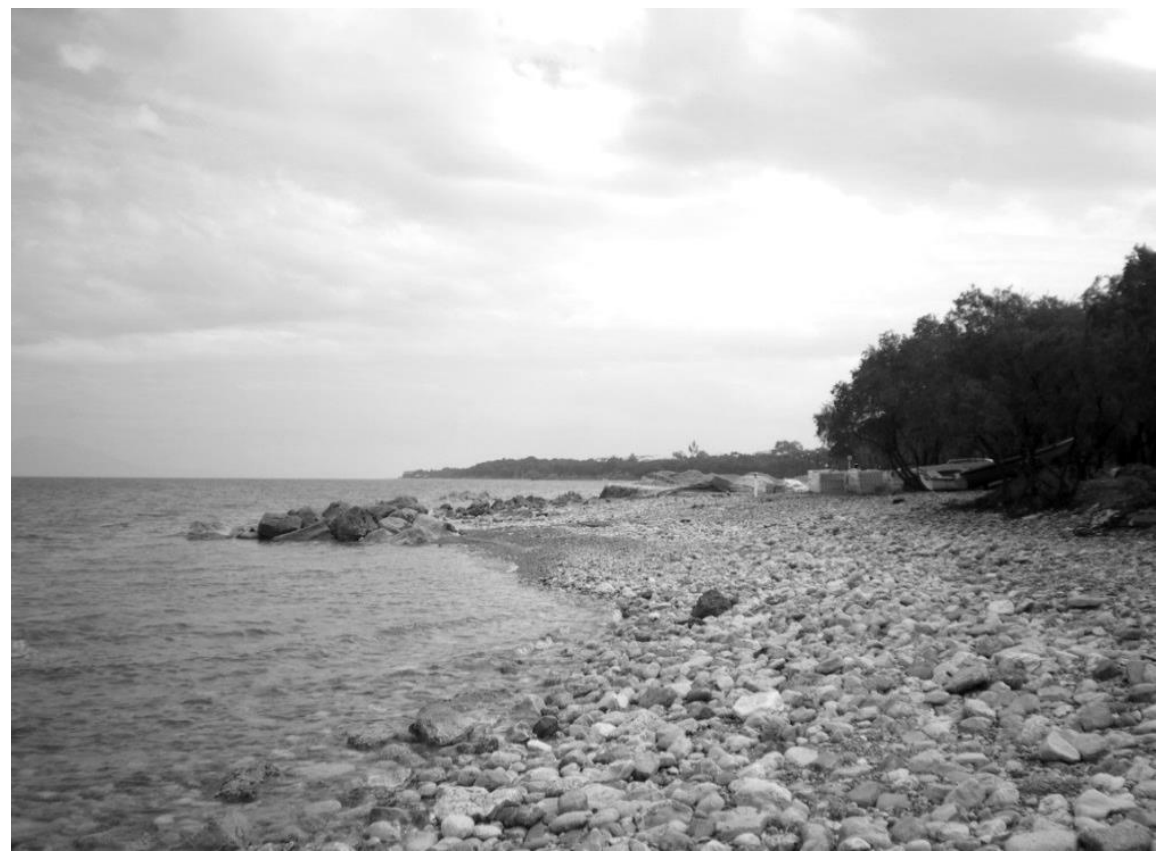

(b)

Figure 4: Photographs from the western part of section 3.1. Photograph (a) was taken in 1992 and photograph (b) in 2011, showing a further retreat of $15-20 \mathrm{~m}$.

The future coastline retreat, owing to the anticipated sea level rise, is given numerically in Table 4; in these estimates no vertical tectonic displacement has been considered, whilst the central part of the study area has been excluded, as it is artificially stabilized by a concrete seawall. According to the IPCC (2007) moderate scenario of sea level rise $(0.38 \mathrm{~m})$ in the next 100 years, the western part is likely to retreat up to $10.9 \mathrm{~m}$ and the eastern part up to $4.1 \mathrm{~m}$. If sea level rises by more than $1 \mathrm{~m}$ (e.g. Rahmstorf, 2007; Pfeffer et al., 2008), then the retreat will exceed that of $23.8 \mathrm{~m}$ in the western part 
and $8.9 \mathrm{~m}$ in the eastern part. These values of coastline retreat, for the moderate scenario, are related to a land loss from $25 \%$ (section 3 ) up to $100 \%$ (section 1) of the Xylokastro beach zone. Land loss will become even higher (54-100\%) in the case of the worst scenario of sea level rise $\geq 1 \mathrm{~m}$ (Table 5).

Table 5. Estimates of future coastline retreat (Rc) and lost area (LA) for each profile and section for a potential sea level rise of $0.38 \mathrm{~m}$ and $1 \mathrm{~m}$ by the year 2100 .

\begin{tabular}{|c|c|c|c|c|c|c|c|}
\hline SLR (m) & Section & Area $\left(m^{2}\right)$ & Profile & $R_{c}(\mathbf{m})$ & $\overline{\mathrm{R}_{\mathrm{c}}}(\mathrm{m})$ & LA $\left(m^{2}\right)$ & LA (\%) \\
\hline \multirow{9}{*}{0.38} & 1.1 & 11,640 & 1 & 15.5 & 10.9 & 11,640 & 100 \\
\hline & & & 2 & 12.9 & & & \\
\hline & 1.2 & 9,130 & 3 & 4.3 & & 3,569 & 39 \\
\hline & 3.1 & 32,800 & 5 & 3.6 & 4.1 & 8,200 & 25 \\
\hline & 3.2 & & 6 & 3.6 & & & \\
\hline & & & 7 & 5.8 & & & \\
\hline & & & 8 & 5.0 & & & \\
\hline & 3.3 & & 9 & 2.3 & & & \\
\hline & & & & & & 23,409 (sum) & $\begin{array}{c}55 \\
\text { (average) }\end{array}$ \\
\hline \multirow{9}{*}{1.0} & 1.1 & 11,640 & 1 & 33.9 & 23.8 & 11,640 & 100 \\
\hline & & & 2 & 28.1 & & & \\
\hline & 1.2 & 9,130 & 3 & 9.4 & & 7,802 & 85 \\
\hline & 3.1 & 32,800 & 5 & 7.9 & 8.9 & 17,800 & 54 \\
\hline & 3.2 & & 6 & 7.9 & & & \\
\hline & & & 7 & 12.6 & & & \\
\hline & & & 8 & 11.0 & & & \\
\hline & 3.3 & & 9 & 4.9 & & & \\
\hline & & & & & & 37,242 (sum) & $\begin{array}{c}80 \\
\text { (average) }\end{array}$ \\
\hline
\end{tabular}

Obviously, the situation described above will have negative economic and most possibly social impact on the population of Xylokastro, as it is almost certain that the infrastructure in the backshore zone will be affected by the accelerated sea level rise, even in the case of the moderate scenario. On the other hand, the Pefkias pine forest (section 3 ) that has undergone the mildest anthropogenic interference, will possibly demonstrate the greatest ability to adapt to the anticipated sea level rise.

\subsection{Assessment of the combined contribution of physical processes and human intervention in the beach zone evolution}

According to the outcome of the present analysis, the geological setting of the broader area and human interference in the coastal stretch under investigation, i.e. a series of natural and anthropogenic factors, have been identified to control the formation and evolution of the Xylokastro beach zone. The natural factors include: the (i) inner continental shelf morphology (I.C.S.M.) whose limited width and increased steepness favor the gravitational mass movements towards the deep basin of the Gulf; (ii) the subaqueous gravitational sediment movements (S.G.S.M.) in response to the existing intensive seismotectonic regime; (iii) the relative sea level change (R.S.L.C.) that accounts for more than 3 $\mathrm{mm} /$ year, over the past decades due to climate change; (iv) the riverine sediment influx (R.S.I.) that refers to the sediment influx of the River Sithas; (v) the near-shore sediment transport (N.S.T.) that includes a long-shore and a cross-shore component (as discussed earlier). Among the anthropogenic factors, the most important seem to be: (i) the waterfront engineering works (W.E.W.) that include mainly the marina, the seawall and the coastal road that affect near-shore sediment transport; (ii) the river basin and main channel regulation (R.B.M.C.R.) that affect the sediment discharge (usually 
negatively). Moreover, in figure 5, the natural and anthropogenic factors identified above, are presented with respect to their spatial and time-period scale of occurrence. The spatial scale includes the clusters of mega (regional), macro $(1-10 \mathrm{~km})$, meso $(\mathrm{m}-\mathrm{km})$ and micro $(\mathrm{mm}-\mathrm{cm})$, while the time scale clusters are micro (sec-min), meso (week-yr), macro (1-10 yr) and mega (continuously).

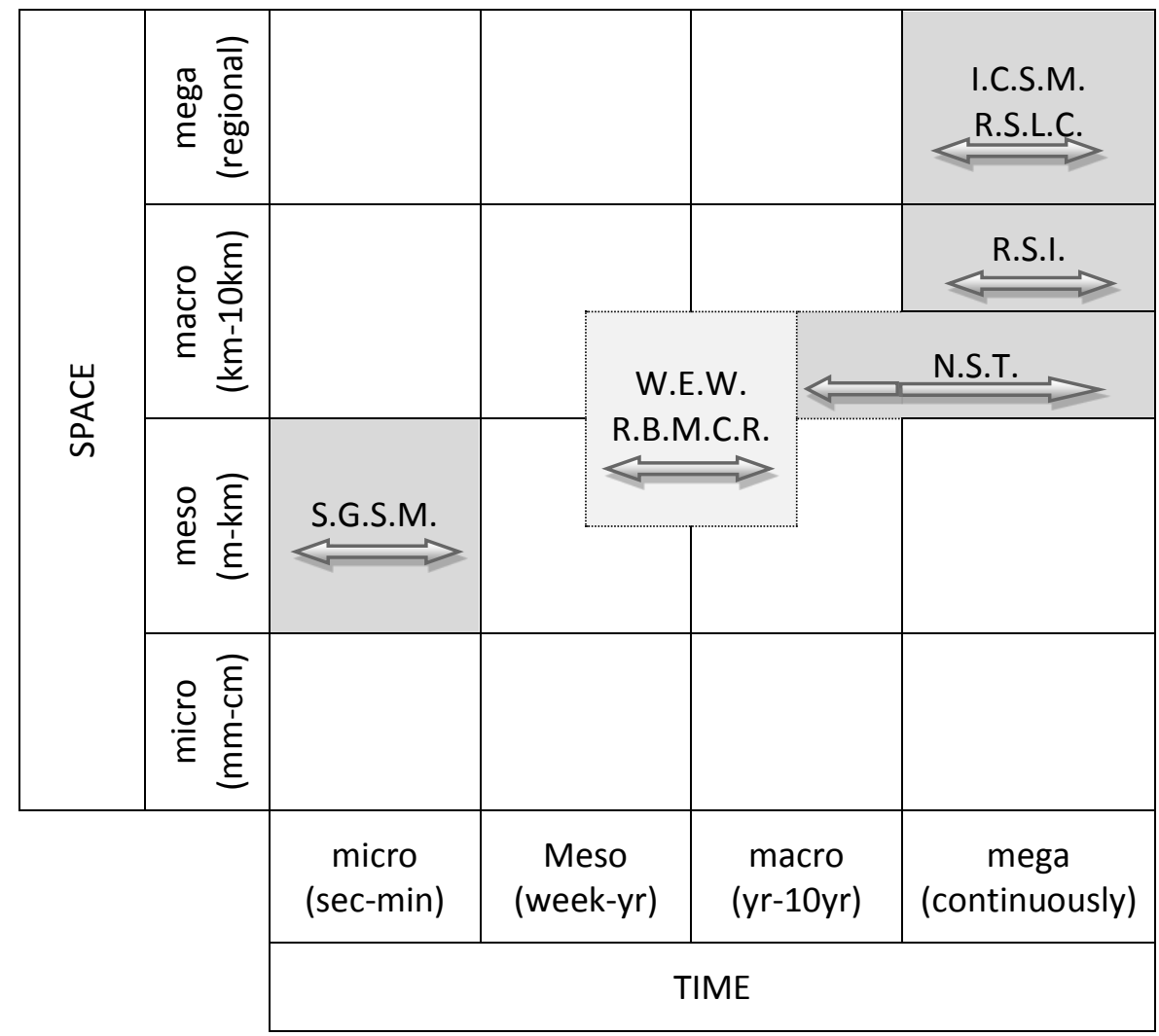

Figure 5: Processes affecting the formation and evolution of the Xylokastro beach zone in different spatial and time scale. Natural factors are highlighted in dark grey whereas anthropogenic factors in light grey. Key: I.C.S.M.: Inner Continental Shelf Morphology; R.S.L.C.: Relative Sea Level Change; R.S.I.: Riverine Sediment Influx; N.S.T.: Near-shore Sediment Transport; S.G.S.M.: Subaqueous Gravitational

Sediment Movements. W.E.W.: Waterfront Engineering Works; R.B.M.C.R.: River Basin and Main Channel Regulation.

\section{Conclusions}

The formation of the Xylokastro beach zone is controlled primarily by the morphotectonics and secondarily by near-shore hydrodynamics and sediment dynamics. Human intervention that also contributes to the beach zone evolution is related mainly to changes in the coastal sediment budget.

The recent and current tendency of shoreline position is the retreat, exhibiting a retreat of about $14 \mathrm{~m}$ on average. The eastern part of the study area (the Pefkias forest) seems to have undergone minimal retreat, as it has been affected to a much lesser extent by the anthropogenic activity compared to the western and central parts of the Xylokastro coastal front area.

The evolution of the Xylokastro coastal area will be characterized by the combined effect of the expected magnitude of sea level rise and the possible seismotectonic activity, if we assume no further human intervention. Nearshore sediment movement is expected to alter in the future morphological conditions (induced by changes in sea level and geology) by adjusting the available sediment budget to the new state. 


\section{Acknowledgements}

The authors would like to thank the PhD candidate S. Dillalos for his contribution in the shoreline tracing with the use of the RTK-DGPS. The authors S. Poulos, S. Petrakis, E. Vassilakis and G. Ghionis during the final stage of the preparation of this manuscript were supported by the project BEACHTOUR (11SYN- 8-1466) of the Operational Program Cooperation 2011, Competitiveness and Entrepreneurship" co-funded by the European Regional Development Fund (ERDF) and the Ministry of Education and Religious Affairs.

\section{References}

Alexandrakis G. and Poulos S.E. (2014), An holistic approach to beach erosion vulnerability assessment, Scientific Reports, 4, 6078; DOI:10.1038/srep06078.

Armijo R., Meyer B., King G., Rigo A. and Papanastassiou D. (1996), Quaternary evolution of the Corinth Rift and its implications for the Late Cenozoic evolution of the Aegean, Geophysical Journal International, 126, 11-53.

Bailard J.A. (1982), "A model for on-offshore sediment transport in the surfzone," Naval Civil Engineering Laboratory Technical Note N-1649, 44 p.

Bailard J.A. and Inman D.L. (1981), An energetics bedload model for plane sloping beach: local transport, Journal of Geophysical Research, 86 (C3), 2035- 2043.

Briole P., Rigo A., Lyon-Caen H., Ruegg J.C., Papazissi K., Mitsakaki C., Balodimou A., Veis G., Hatzfeld D. and Deschamps A. (2000), Active deformation of the Corinth rift, Greece: Results from repeated Global Positioning System surveys between 1990 and 1995, Journal of Geophysical Research, 105(B11), 25605-25625.

Cai F., Su X., Liu J., Li B. and Lei G. (2009), Coastal erosion in China under the condition of global climate change and measures for its prevention, Progress in Natural Science, 19, 415-426.

Castelle B., Le Corre Y. and Tomlinson R.B. (2008), Can the Gold Coast beaches withstand extreme events?, GeoMarine Letters, 28, 23-30.

CERC (1984),. Shore Protection Manual. U.S. Army Corps of Engineers, Coastal Engineering Research Center. U.S. Government Printing Office, Washington. D.C., 652 p.

Collier R.E., Leeder M.R., Rowe P.J. \& Atkinson T.C. (1992), Rates of tectonic uplift in the Corinth and Megara basins, Central Greece, Tectonics, 11(6), 1159-1167.

Dan, S., Stive, M.J.F., Walstra, D.J.R. and Panin, N. (2009), Wave climate, coastal sediment budget and shoreline changes for the Danube Delta. Marine Geology, 262(1-4):39-49.

Dean R.G. (1991), Equilibrium Beach Profiles: Characteristics and Applications, Journal of Coastal Research, 7, 53-84.

Doutsos T., Kontopoulos N. and Poulimenos G. (1988), The Corinth - Patras rift as the initial stage of continental fragmentation behind an active island arc (Greece), Basin Research, 1, 177-190.

Doutsos T. and Piper D.J.W. (1990), Listric faulting, sedimentation and morphological evolution of the Quaternary eastern Corinth rift, Greece: First stages of continental rifting, Geological Society of America Bulletin, $102,812-829$.

Eurosion (2004), Living with coastal erosion in Europe: sediment and space for sustainability. A guide to coastal erosion management practices in Europe, National Institute for Coastal and Marine Management of the Netherlands, 164 p. http://www.eurosion.org/ reports-online/reports.html.

Ferentinos G., Papatheodorou G. and Collins M.B. (1988), Sediment transport processes on an active submarine fault escarpment: Gulf of Corinth, Greece, Marine Geology, 65, 243-269.

Folk P.L. (1974), Petrology of Sedimentary Rocks. Hemphill Publishing Company, Austin, Texas, 183 p.

Frihy O.E. and Lotfy M.F. (1997), Shoreline changes and beach-sand sorting along the northern Sinai coast of Egypt,Geo-Marine Letters, 17, 140-146.

Fritz H.M, Blount C.D., Albusaidi F.B. and Al-Harthy A.H.M. (2010), Cyclone Gonu Storm Surge in Oman, Estuarine Coastal and Shelf Sciences, 86(1), 102-106.

Ghionis G. and Ferentinos G. (2002), Wave-induced shoreline changes along the coast of Aegialia (Greece). In: Procceedings 6th Hellenic Geographical Conference, Thessaloniki, Greece, 1, 46-53. 
Gourdoumpas I., Poulos S., Nastos P. and Maroukian X. (2010), A study of the water and sediment fluxes of the rivers of the north Peloponnesos discharging into Korinthiakos Gulf, Proceedings of the 8th Panhellenic Geographical Congress, 5-8 October, Athens, vol. 1, pp. 229-237 (in Greek).

Hasiotis T., Papatheodorou G., Bouckovalas G., Corbau C. and Ferentinos G. (2002), Earthquake-induced coastal sediment instabilities in the western Gulf of Corinth, Greece, Marine Geology, 31, 1-17.

Hattori M. and Kawamata R. (1980), Onshore-Offshore Transport and Beach Profile Changes, Proceedings of 17th Conference on Coastal Engineering, ASCE, New York, vol. 2, pp. 1175-1193.

Heezen B., Ewing M. and Johnson G. (1966), The floor of Corinth Gulf. Deep-Sea Research, 13, 381-411.

Hollenstein C., Muller M.D., Geiger A. and Kahle H.G. (2008), Crustal motion and deformation in Greece from a decade of GPS measurements, 1993-2003, Tectonophysics, 449(1-4), 17-40.

HNHS (Hellenic Navy Hydrographic Service) (2005), Tides of the Greek Ports, Publication of Hellenic Navy Hydrographic Service, Athens, 28 p.

IPCC (Intergovernmental Panel on Climate Change) (2007), Climate Change 2007: Impacts, Adaptation and Vulnerability, Contribution of Working Group II to the Fourth Assessment Report of the Intergovernmental Panel on Climate Change. Cambridge University Press, Cambridge, United Kingdom and New York, N.Y., USA.

List J.H., Farris A.S. and Sullivan C. (2006), Reversing Storm Hotspots on Sandy Beaches: Spatial and Temporal Characteristics, Marine Geology, 226, 261-279.

Lykousis V. (1991), Submarine slope instabilities in the Hellenic Arc Region, Northeastern Mediterranean Sea, Marine Geotechnology, 10, 83-96.

McGranahan G., Balk D. and Anderson B. (2007), The rising tide: assessing the risks of climate change and human settlements in low elevation coastal zones, Environment and Urbanization, 19, 17-37.

McNeil L. and Collier R. (2004), Uplift rates of the eastern Eliki fault segment, Gulf of Corinth, Greece, inferred from Holocene and Pleistocene terraces, Journal of the Geological Society of London, 161, 81-92.

McNeill L.C., Cotterill C.J., Henstock T.J., Bull J.M., Stefatos A., Collier R.E.L., Papatheodorou G., Ferentinos G. and Hicks S.E. (2005), Active faulting within the offshore western Gulf of Corinth, Greece: implications for models of continental rift deformation, Geology, 33(4), 241-244.

Mendoza E.T. and Jimenez J.A. (2006), Storm induced beach erosion potential on the Catalonian coast, Journal of Coastal Research, 48, 81-88.

Nicholls R.J., Wong P.P., Burkett V.R., Codignotto J.O., Hay J.E., Mclean R.F., Ragoonaden S. and Woodroffe C.D., (2007), Coastal systems and low-lying areas. (In:) Parry, M. L., Canziani, O. F., Palutikof, J. P., van der Linden, P. J., Hanson, C. E., editors. Climate change 2007: impacts, adaptation, and vulnerability. Contribution of working group II to the fourth assessment report of the Intergovernmental Panel on Climate Change. Cambridge, UK: Cambridge University Press, pp. 315-356.

Papatheodorou G. and Ferentinos G. (1997), Submarine and coastal sediment failure triggered by the 1995, $\mathrm{Ms}=6.1 \mathrm{R}$ Aegion earthquake, Gulf of Corinth, Greece, Marine Geology, 137, 287-304.

Perissoratis C., Mitropoulos D. and Angelopoulos I. (1984), The role of earthquakes in inducing sediment mass movements in the eastern Korinthiakos Gulf. An example from the February 24-March 4, 1981 activity, Marine Geology, 55, 35-45.

Perlin A. and Kit E. (1999), Longshore sediment transport on the Mediterranean coast of Israel, Journal of Waterway, Port, Coastal and Ocean Engineering, 125(2), 80-87.

Pfeffer W.Y., Harper J.T. and O'neel S. (2008), Kinematic constrains on Glacier Contributions to 21st - Century Sea Level Rise, Science, 321 (5894), 1340-1343.

Rahmstorf S. (2007), Sea - Level Rise: A semi-Empirical Approach to Projecting Future, Science, 315, 368-370.

Ryu S.O. (2003), Seasonal variation of sedimentary processes in a semi-enclosed bay: Hampyong bay, Korea, Estuarine, Coastal and Shelf Science, 56(3-4), 481-492.

Sánchez-Arcilla A., Mendoza E.T., Jiménez J.A., Peña C., Galofré J. and Novoa M. (2008), Beach erosion and storm parameters. Uncertainties for the Spanish Mediterranean, Proceedings of $31^{\text {st }}$ International Conference on coastal engineering, Hamburg, Germany, pp. 2352-2362.

Tsimplis M.N. (1994), Tidal Oscillations in the Aegean and Ionian Seas, Estuarine, Coastal and Shelf Science, 39, 201-208. 
Van Rijn L.C. (1993), Principles of Sediment Transport in Rivers, Estuaries and Coastal Seas. Aqua Publications, Amsterdam, The Netherlands.

Vassilakis E., Royden I. and Papanikolaou D. (2011), Kinematic links between subduction along the Hellenic trench and extension in the Gulf of Corinth, Greece: A multidisciplinary analysis, Earth and Planetary Science Letters, 303(1-2), 108-120.

Zviely D., Kit E. and Klein M. (2007), Longshore sand transport estimates along the Mediterranean coast of Israel in the Holocene, Marine Geology, 237, 61-73. 